\title{
The Impact of Unwanted Pregnancy in Adolescents toward Pregnancy Care: A Systematic Review
}

\author{
Ermiati Ermiati $^{1,2 *} \mathbb{D}$, Restuning Widiasih ${ }^{2}$ (D) Henny Suzana Mediani $i^{3}$ \\ ${ }^{1}$ Doctoral Study Program, Faculty of Medicine, Universitas Padjadjaran, Bandung, Indonesia; ${ }^{2}$ Department of Maternity Nursing, \\ Faculty of Nursing, Universitas Padjadjaran, Bandung, Indonesia; ${ }^{3}$ Department of Pediatric Nursing, Faculty of Nursing, \\ Universitas Padjadjaran, Bandung, Indonesia
}

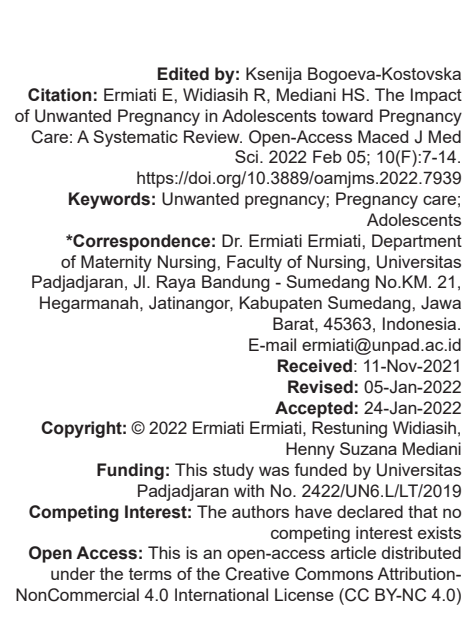

\section{Abstract}

BACKGROUND: The unwanted pregnancy in adolescents causes the rejection of pregnancy and fetus itself AIM: The purpose of this literature review is to determine the impact of unwanted pregnancy on pregnancy care in adolescents.

METHODS: The method used a systematic review. The data search using an advanced search techniques on databases and search engines such as CINAHL, PubMed, and Google Scholar. The literature search is based on qualitative study design criteria, national and international articles, published in the past 10 years (2011-2021), and written in Indonesian and English.

RESULTS: From the six articles reviewed, it was found that there were 10 impacts of adverse events on pregnancy care in adolescents, namely, not doing ANC, trying to abort the pregnancy, not eating healthy foods with balanced nutrition, not doing physical activity and sports, not taking Fe tablets, getting lack of sleep and rest, ignoring the personal hygiene, being introvert, not doing fetal stimulation, and depression.

CONCLUSION: Adolescents, who experience unwanted pregnancy, tend not to do ANC, behave in harming to themselves and their fetus; therefore, the further research can be done regarding the development of a model of care in families with adolescents experiencing unwanted pregnancy.

\section{Introduction}

In the world, every day there are 20,000 adolescent girls under the age of 18 giving birth and every year, it is estimated that 2.5 million adolescents perform abortions and as many as 70,000 adolescents died due to pregnancy complications [1]. The unhealthy sexual behavior is stated in the results of the Ministry of Health and KPAI survey in 2013 that as many as $20 \%$ of 94,270 women who experience pregnancy outside marriage are teenagers and as many as $21 \%$ of them have had an abortion [2]. Pregnancy in adolescents will cause a decrease in the quality of the fetus being born because one of the factors that affect the quality of the fetus is the readiness of the mother [3].

The impact of this unwanted pregnancy is in the form of physical and psychological impacts. Unwanted pregnancies in adolescents cause serious problems for the mother and fetus, the main complications in neonates are premature, low birth weight, and perinatal death. While in the mother, there are hypertension, abortion, urinary tract infection (UTI), and premature rupture of membranes [4]. So that adolescents with unwanted pregnancy require treatment to health services because of the physical and psychological impacts that can lead to morbidity and mortality. However, the rejection of pregnancy is come from teenager themselves, environment, and community. It caused teenagers with unwanted pregnancy reluctant for antenatal care. According to Azevedo et al., one of the causes of pregnancy complications in adolescents is the lack of care during pregnancy [4].

Pregnancy care that is carried out properly will improve the welfare of the mother and fetus and be able to detect and treat problems in pregnancy early, while if pregnancy care is not carried out properly it will affect the condition of pregnancy, fetal growth will even cause pregnancy and childbirth complications that will threaten the baby's life and mothers, in addition to poor prenatal care will affect the growth and development of babies born [5].

Therefore, it is necessary to search and analyze the research literature related to the behavior of adolescents with unwanted pregnancies toward pregnancy care to find out what behaviors are carried 
out by adolescents with these conditions. The purpose of writing this literature review is to determine the impact of unwanted pregnancy in adolescents on pregnancy care.

\section{Methods}

\section{Methods used}

The method used in the literature is a narrative review using the Preferred Reporting Items for Systematic Review (PRISMA). In this study, we identified the findings on the research topic. The data used are secondary data taken from scientific articles in Indonesian and English from 2011 to 2021 with a database used to search for articles on the impact of unwanted pregnancy on adolescent pregnancy care.

\section{The strategy of literatures search}

The literature search was carried out comprehensively through electronic databases, namely, Google Scholar and PubMed. Search literature based on qualitative study design criteria, national and international articles, published in the past 10 years (2011-2021), and in Indonesian and English. We used the keywords of Adolescent Pregnancy OR Adolescence pregnancies OR Adolescent pregnancy OR Adolescent pregnancies OR Teen pregnancy OR Teen pregnancies AND Unwanted Pregnancy OR Unwanted Pregnancies OR Unintended Pregnant OR Unintended Pregnancy OR Unplanned Pregnancy AND Pregnancy Care OR Pregnancies Care OR Antenatal Care (ANC) AND Teen OR Youth OR Children AND Unwanted pregnancies.

The next step is the article will be specified again using the inclusion criteria that have been set in the inclusion criteria table and the exclusion criteria used in the literature search in this literature review. The inclusion criteria for this article search were the year published in the past 10 years (2011-2021), using Indonesian and English, with the type of literature is all full-text research articles, and a literature focus on the impact of unwanted pregnancy on pregnancy care in adolescents with a sample population of adolescents with unwanted pregnancy. The exclusions criteria were article year from 2011 to 2021, Indonesian and English language, article with the type of meta-analysis and systematic review, and respondents aged $>15$ years old.

The results of entering keywords are obtained according to the keywords as many as 2051 articles. Furthermore, the article is adjusted to the inclusion and exclusion criteria for screening with the criteria of the year published in the past 10 years (2011-2021), full-text availability, being written in Indonesian or English, using all types of articles except meta-analysis and systematic review, focusing on the literature on the impact of unwanted pregnancy toward pregnancy care in adolescents, and the population of adolescents with unwanted pregnancies. It was obtained 710 articles. Then, the articles were screened based on titles and abstracts that matched the literature theme, the results were six articles. After that, the article is read, identified, and analyzed (Figure 1).

\section{Results}

Based on the article search results, there were six articles that met the inclusion criteria and were assessed with a critical appraisal check from JBI (Table 1). We founded 10 impacts of unwanted pregnancy on pregnancy care in adolescents, namely, not doing the ANC, abortion, not eating healthy foods with balanced nutrition, not taking the blood boosting (Fe) tablets, not doing physical activity and sports, lack of sleep and rest, ignoring the personal hygiene, not doing the fetal stimulation, being introvert, and depression.

\section{Discussion}

\section{Not doing the ANC}

ANC is a pregnancy test to optimize the mental and physical health of pregnant women and avoid the risk of complications in pregnancy [6]. Based on the results of a literature review, it was found that the impact of unwanted pregnancy on pregnancy care in adolescents, that is, adolescents did not do ANC [2].

This ANC practice is important as an effort for safe motherhood in accelerating the reduction of maternal mortality. According to Fitrayeni, Suryati, and Faranti, ANC is useful for maintaining the maternal health during pregnancy, childbirth, and postpartum, as well as ensuring that babies are born healthy, the process of pregnancy and childbirth is safe and satisfying, monitoring possible pregnancy risks, planning an appropriate optimal management for highrisk pregnancies, and reducing both maternal and fetal morbidity and mortality [6]. In line with the research of Wakhidah and Cahyo, it was stated that adolescents with unwanted pregnancies needed good ANC to maintain the health of the mother and fetus, and to prevent complications during pregnancy, childbirth, and postpartum [2]. 


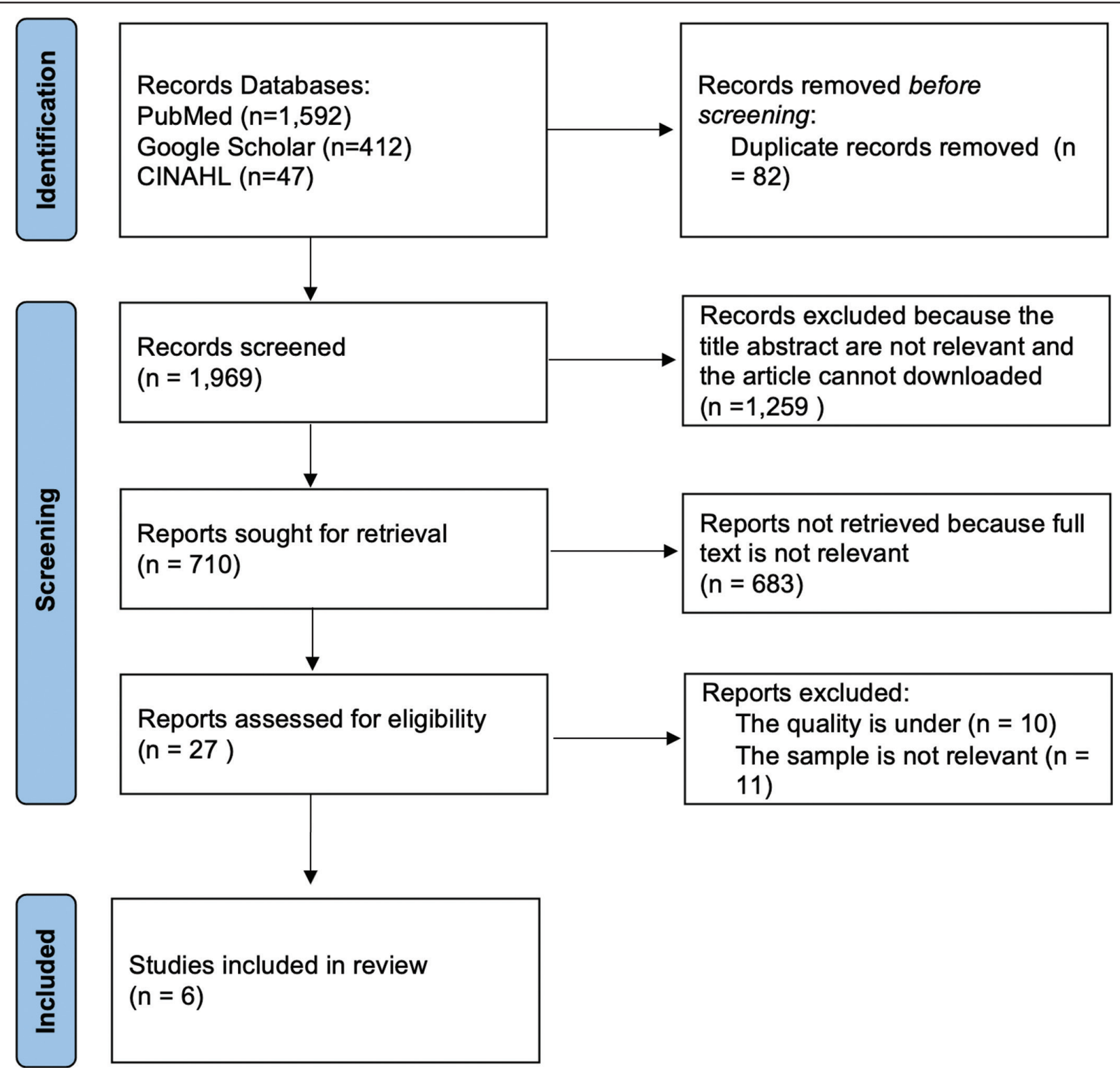

Figure 1: PRISMA flow diagram

The ANC care that is not optimal yet results in risks and complications on pregnancy that is not being detected early. Therefore, adolescents experiencing unwanted pregnancy need to conduct ANC visits at least 4 times as an effort to reduce complications related to pregnancy, childbirth, and postpartum in mothers and newborns [7].

\section{Abortion}

Based on Elvahra's research, it is stated that intentional abortion can violate applicable legal provisions and can threaten the lives of mothers and babies [8]. Abortion is carried out by adolescents due to feeling depressed. So that it causes sociocultural and economic barriers that force teenagers to have abortions. This is in line with Amalia's research, which states that adolescents who experience adverse events will be psychologically depressed which results in adolescents wanting to have an abortion [9]. Abortion is done because psychosocially adolescents are not ready to undergo the pregnancy. So that they think that having an abortion is the best solution when experiencing an unwanted pregnancy [10].

Based on the articles that have been analyzed, there are several ways that teenagers do to abort their pregnancy, some are successful, but some are physically injured. They conducted foot massage, consuming young pineapple and fermented food, jumping, and comsuming menstrual-stimulation drugs.

Abortion is considered as a dangerous and lifethreatening procedure. Based on Elvahra's research, abortion will have an impact on the health and physical safety of the mother [8]. The impacts that arise include sudden death due to heavy bleeding, failed coagulation, serious infections around the uterus and a torn uterus, damage to the cervix which will cause defects in the next child, breast cancer due to an imbalance of the hormone estrogen, ovarian cancer, cervical cancer, and abnormalities in the placenta will even lead to 
Table 1: Article analysis

\begin{tabular}{|c|c|c|c|c|}
\hline Title & Objective & Sample & Methods & Impact \\
\hline $\begin{array}{l}\text { Factors related to the } \\
\text { practice of antenatal care in } \\
\text { adolescents with unwanted } \\
\text { pregnancies (study in the area } \\
\text { of UPT Puskesmas Ponjong } 1 \\
\text { Kabupaten Gunungkidul) }\end{array}$ & $\begin{array}{l}\text { Knowing the relationship } \\
\text { between ANC practice factors } \\
\text { in adolescents with unwanted } \\
\text { pregnancy }\end{array}$ & $\begin{array}{l}\text { Population: All adolescents with } \\
\text { unwanted pregnancy in UPT Health } \\
\text { Center Ponjong } 12014 \text { and } 2015 . \\
\text { Sample: } 43 \text { people by total } \\
\text { sampling }\end{array}$ & $\begin{array}{l}\text { Analytical } \\
\text { descriptive with } \\
\text { cross sectional } \\
\text { approach }\end{array}$ & $\begin{array}{l}\text { - Not taking additional tablets blood during pregnancy } \\
\text { - Lack of ANC }\end{array}$ \\
\hline $\begin{array}{l}\text { Analysis of Behavioral Factors } \\
\text { for Unwanted Pregnancy in } \\
\text { adolescents in Kecamatan } \\
\text { Karangrayung kabupaten } \\
\text { Grobongan }\end{array}$ & $\begin{array}{l}\text { Analyzing pregnancy care } \\
\text { behavior in adolescents with } \\
\text { adverse events }\end{array}$ & $\begin{array}{l}\text { Sample: } 6 \text { people are chosen by } \\
\text { purposive sampling }\end{array}$ & $\begin{array}{l}\text { Qualitative } \\
\text { through } \\
\text { interviews. }\end{array}$ & $\begin{array}{l}\text { - Consuming young pineapple and tape } \\
\text { - Consuming menstrual smoothing drugs to abort the } \\
\text { pregnancy } \\
\text { - Not doing much activity just spending time at home } \\
\text { - Never telling anyone if he feels sick, nauseous, etc. } \\
\text { - Lack of fulfillment of nutrition } \\
\text { - Ignoring personal hygiene }\end{array}$ \\
\hline $\begin{array}{l}\text { Pregnancy care behavior in } \\
\text { adolescents with unwanted } \\
\text { pregnancies in Kecamatan } \\
\text { Widodaren Kabupaten Ngawi }\end{array}$ & $\begin{array}{l}\text { Knowing the behavior of } \\
\text { unwanted pregnancy care in } \\
\text { adolescents }\end{array}$ & $\begin{array}{l}\text { Sample: Five teenagers who } \\
\text { experienced unwanted pregnancy } \\
\text { and additional informants, namely } \\
\text { parents, midwives, traditional birth } \\
\text { attendants, informant neighbors }\end{array}$ & Qualitative & $\begin{array}{l}\text { - Teenagers are getting lack of support to do the practice of } \\
\text { ANC } \\
\text { - Massage with feet to abort the fetus } \\
\text { - Do not consume balanced nutritious food } \\
\text { - Not getting enough rest or not resting for 6-7 h a day } \\
\text { - Do not carry out fetal stimulation } \\
\text { - Not maintaining personal hygiene by washing hands with } \\
\text { soap and running water } \\
\text { - Not brushing your teeth regularly and having your teeth } \\
\text { checked } \\
\text { - Not doing physical activity like pregnancy exercise } \\
\text { - Do not regularly drink pregnant milk } \\
\text { - Lack of appetite }\end{array}$ \\
\hline $\begin{array}{l}\text { Beyond the discourse of } \\
\text { reproductive choice: narratives } \\
\text { of pregnancy resolution among } \\
\text { Latina/o teenage parents }\end{array}$ & $\begin{array}{l}\text { Researching how Latino teens } \\
\text { share their experiences with } \\
\text { unwanted pregnancies }\end{array}$ & $\begin{array}{l}21 \text { adolescents with unwanted } \\
\text { pregnancy }\end{array}$ & Qualitative & $\begin{array}{l}\text { Having an abortion because they think abortion is the best } \\
\text { solution for adverse events }\end{array}$ \\
\hline $\begin{array}{l}\text { Adolescent responses to an } \\
\text { unintended pregnancy in } \\
\text { Ghana: A qualitative study }\end{array}$ & $\begin{array}{l}\text { Knowing the experiences and } \\
\text { perceptions of adolescents } \\
\text { who have experienced } \\
\text { a recent pregnancy and } \\
\text { experienced an abortion }\end{array}$ & $\begin{array}{l}\text { Teenagers aged } 10-19 \text { years who } \\
\text { terminated pregnancy }\end{array}$ & $\begin{array}{l}\text { Qualitative with } \\
\text { FGD discussions }\end{array}$ & $\begin{array}{l}\text { - Respondents reported feeling sad, depressed and regretful } \\
\text { - Men will deny pregnancy and suggest abortion } \\
\text { - Parents get angry and throw their child away } \\
\text { - Parents seclude their child until delivery to avoid } \\
\text { embarrassment }\end{array}$ \\
\hline $\begin{array}{l}\text { "You just have to learn to keep } \\
\text { moving on:" young women's } \\
\text { experiences with unplanned } \\
\text { pregnancy in the Cook Island }\end{array}$ & $\begin{array}{l}\text { Having a complete } \\
\text { understanding of the } \\
\text { experience of unwanted } \\
\text { pregnancy }\end{array}$ & $\begin{array}{l}10 \text { people who have experienced } \\
\text { an unwanted pregnancy } \\
\text { The sampling technique uses a } \\
\text { combination of purposive sampling } \\
\text { and snowball sampling }\end{array}$ & $\begin{array}{l}\text { Qualitative } \\
\text { descriptive } \\
\text { with interview } \\
\text { technique }\end{array}$ & $\begin{array}{l}\text { - At the beginning of pregnancy refused even to do various } \\
\text { ways to abort the womb. } \\
\text { - Drinking a mixture of drugs given by his family whose } \\
\text { contents are not known, causes nausea and vomiting } \\
\text { - Banged his stomach against the chair causing bruising } \\
\text { - Trying to visit an abortion practice } \\
\text { - At the age of } 6-7 \text { months pregnant begins to accept the } \\
\text { condition of her pregnancy and begins to behave positively } \\
\text { to become a mother }\end{array}$ \\
\hline
\end{tabular}

infertility. In addition, abortion will also have an impact on the psychological health of the mother or abortion syndrome, such as loss of self-esteem, screaming hysterically, repeatedly having nightmares about the baby, wanting to commit suicide, using illegal drugs, and even not being able to enjoy sex. Therefore, the role of nurses in maternity nursing is as an educator and a counselor for adolescents related to decision making in increasing adolescent knowledge in actions that will be carried out which are at high risk to health, whether life threatening or not.

\section{nutrition}

\section{Not eating healthy foods with balanced}

Nutrition is the most important element for the health of the body that functions as a source of energy [11]. With good nutritional status, the body will be on normal/ideal weight, the body is less susceptible to infectious diseases, increasing work productivity, and protecting from chronic diseases and premature death. Nutrition is very necessary especially for pregnant women during the process of fetal growth and the growth of various organs of the body as a supporter of the pregnancy process [12].
Based on the results of the research review, it was found that unwanted pregnancy caused adolescents not to consume healthy foods with balanced nutrition. It was stated that adolescents with unwanted pregnancy experienced a decrease in appetite, did not eat healthy foods such as consuming young pineapple and fermented food (tape) in early pregnancy, and did not regularly drink pregnancy milk. This diet will affect the condition of the mother and fetus. The food consumption of pregnant women must meet the needs of the mother and her baby.

According to Muliawati, the nutritional needs of pregnant women include carbohydrates, protein, fat, vitamins, calcium, and iron [13]. This is what makes nutrition during pregnancy very important because it is related to the food intake obtained will affect the health of the mother and baby and affect breastfeeding later. In line with Ernawati's research, which states that balanced nutrition is very important for snacks so that mothers can maintain optimal nutritional status [12]. With balanced nutrition, pregnant women can have a safe pregnancy. In addition, balanced nutrition will also affect physical and mental health and obtain sufficient energy for breastfeeding later.

From the explanation above, it can be concluded that the consumption of healthy food with 
balanced nutrition during pregnancy is very much needed for the baby and mother. If the mother's daily diet does not meet the needs of the fetus, the fetus will take the supplies that are in the mother's body such as fat cells as a source of calories and iron as a source of iron. Therefore, pregnant women must have a good nutritional status by consuming healthy foods with balanced nutrition in various proportions and amounts.

\section{Not taking the blood boosting (Fe) tablets}

Iron $(\mathrm{Fe})$ is an essential microelement for the body which is needed for the formation of hemoglobin. During pregnancy, the need for iron $(\mathrm{Fe})$ in the body increases, especially in the second and third trimesters, the amount of iron (Fe) absorbed from food and reserves in the body usually does not meet the needs of the mother during pregnancy. So that $\mathrm{Fe}$ tablets are needed to help restore hemoglobin levels in the blood which are useful for preventing anemia during pregnancy [14].

Based on the results of the review article, it was found that the impact of adverse events on pregnancy care in adolescents was not taking blood added tablets during pregnancy [2]. Based on the results of Amanah's research, pregnant women who do not take blood boosting tablets will be at risk of anemia in pregnancy, which can result in impaired fetal growth and bleeding in labor [15].

Blood boosting tablets during pregnancy are given as much as one tablet every day for 90 days during pregnancy which aims to prevent and treat anemia problems during pregnancy so that hemoglobin levels increase rapidly. In addition, based on Andrew's research in Juwita, it is stated that giving Fe tablets can also reduce the incidence of premature births and low birth weight babies [16]. Meanwhile, if the mother does not take Fe tablets, she has a shorter gestational age and has a risk of giving birth to premature babies [17].

From the data above, it can be concluded that taking Fe tablets during pregnancy can protect the mother from malnutrition, impaired fetal growth, and prevent anemia. If the mother is iron deficient during pregnancy, the baby's iron at birth will not be adequate. Meanwhile, the iron is needed for the development of the baby's brain at the beginning of birth. Therefore, mothers need to take blood boosting tablets during pregnancy.

\section{Not doing physical activity and sports}

Physical activity during pregnancy with the right portion will benefit both the health of the mother and baby. Physical activity during pregnancy can reduce the risk of emotional disorders commonly experienced by pregnant women. Physical activity can also prevent the risk of gestational diabetes, several studies have found a decrease in blood glucose levels at 24-28 weeks of gestation from oral glucose tolerance tests in pregnant women who are physically active. Moreover, physical activity can also increase the rate of growth and weight of the baby [18]. Based on the results of the article reviewed, adolescents with unwanted pregnancy are lack of physical activity such as pregnancy exercise. Pregnancy exercise is useful to improve maternal blood circulation and to assist mothers in dealing with childbirth [19]. A study revealed that mothers who do physical activity or sports can provide benefits to the condition of the fetus. So therefore, by doing physical activity/sports, the fetal heart is getting stronger and healthier, namely, the heart rhythm does not beat fast but slows down regularly [20]

\section{Lack of sleep and rest}

Adolescents with adverse events will also affect pregnancy care in terms of rest and sleep patterns. It was reported that adolescents with unwanted pregnancy did not have enough rest, they slept $<6-7 \mathrm{~h}$ a day [21]. According to Sinta et al., the quality of sleep in pregnant women can affect the condition of the mother during pregnancy, where the quality of this sleep will affect the increase in blood pressure so that it can potentially cause preeclampsia in pregnancy [22]. To prevent this, pregnant women should pay attention to some tips that can be done to improve sleep quality for the better that is not sleeping when hungry because it will make sleeping less comfortable, limiting water consumption before going to bed so as not to wake up at night because you want to urinate, adjusting the environment to sleep as comfortably as possible, and making sure to sleep with a comfortable mattress and pillows. Making a regular sleep schedule by going to bed and getting up at the same time and doing regular exercise are able to improve sleep quality [22].

\section{Ignoring the personal hygiene}

Another impact is that adolescents do not maintain their personal hygiene, by washing their hands with soap and running water, and not brushing their teeth regularly nor having their teeth checked by a doctor [21], [23]. Personal hygiene in pregnant women is very important to reduce the possibility of infection. One form of personal hygiene is dental hygiene. According to Subrakti, the dental hygiene of pregnant women aims to protect the teeth from food residue that is still left in the teeth which causes tooth decay [24]. When teeth are damaged or cavities will increase the risk of infection, as if the mother has an infection, it is likely that bacteria will also affect the condition of the fetus.

Pregnant women must realize the importance of maintaining oral health during pregnancy for themselves and the fetus they are carrying so that they can avoid 
oral diseases that can affect pregnancy. Poor oral and dental health in pregnant women can have an effect on the fetus such as premature babies and low birth weight in addition to the baby's dental and oral health later [25].

\section{Not doing the fetal stimulation}

Adolescents with unwanted pregnancy in early pregnancy tend not to accept and ignore their fetus, so they do not carry out fetal stimulation [21]. According to Suri and Nelliraharti, stimulating the fetus is useful for fetal brain development, especially stimulation in the form of the mother's voice which can increase the bond between the mother and the prospective child [26].

Stimulation can be in the form of sound or touch. Expressions of affection that the mother give to the fetus will give peace of mind to the fetus [27]. When the mother communicates with the baby, physiologically the hypothalamus will send a message to the pituitary gland to secrete endorphins. These endorphins function to inhibit stress where this stress will cause vasoconstriction [28]. When stress hormones are inhibited, it will automatically increase blood circulation between mother and fetus. This condition will increase fetal movement due to an increase in energy [27]. Another stimulus is by physical touch. The touch given to the fetus will provide comfort. Based on research, it was stated that maternal touch has a positive effect on fetal movement [27].

Mothers who do not provide stimulation to their fetuses during pregnancy will hinder the growth of the baby's brain and babies born tend to have difficult temperaments [3]. Therefore, it is important for mothers to provide stimulation while the fetus is still in the womb.

\section{Being introvert}

In their daily life, adolescents with unwanted pregnancies only spend time at home and never tell anyone if they feel sick, nauseous, etc. [23]. The results of this study are in line with the results of research conducted by Malik, Astuti, and Yulianti that the initial response of adolescents when they first find out that they are pregnant is to remain silent and think positively that they are not pregnant, both of which have the same meaning that is to hide their pregnancy [29]. This selfdisclosure is related to barriers in communication when conveying the news that she is pregnant, especially to her parents. One of the communication barriers in adolescents with unwanted pregnancies is in the form of internal factors, where there is a thought in them in the form of fear of anger from their parents [30].

Based on the analysis of the journal, it was found that parents and closest people played a role in the problem of closing themselves off in adolescents with unwanted pregnancy. They tend to throw away their children and isolate them until they give birth to avoid embarrassment in social environment. In addition, men tend to deny pregnancy and suggest abortion. This makes adolescents with unwanted pregnancy become sad, depressed, and regret their actions [31].

Adolescents with unwanted pregnancy tend to close themselves off because they feel that their pregnancy is a disgrace that must be covered up, so this causes them to be afraid and embarrassed to leave the house. This fear will result in late and irregular ANC visits due to pressure and negative views from the people around. If pregnancy care is not carried out properly, it will affect the condition of pregnancy and fetal growth, it will even cause pregnancy and delivery complications that will threaten the lives of the baby and mother. Besides, that poor pregnancy care will affect the growth and development of the newborn baby [5].

Closing self due to an unwanted pregnancy is a wrong decision, especially for a teenager, whose knowledge about pregnancy and prenatal care is still relatively low. So that there is a need for openness regarding their condition to get education and help with proper pregnancy care, so as to prevent complications that may occur during pregnancy and childbirth.

\section{Depression}

Adolescents with unwanted pregnancy are very likely to experience depression [31]. The results of a literature study conducted by Boobpamala, Kongvattananon, and Somprasert, depression in pregnant adolescents occurs due to five factors, namely, first, the perspective of social stigma, adolescents with unwanted pregnancy feel that the surrounding community rejects their pregnancy, in addition, they also feel that health workers see themselves differently from other normal mothers [32]. This may be a factor that causes adolescents with adverse events to be reluctant to have their pregnancy checked and is reluctant to routinely perform ANC. The second factor is low selfesteem. Adolescents with unwanted pregnancy show sadness, loneliness, stress, and depression when the family rejects their pregnancy. According to the research of Jesse, Kim, and Herndon, low social support and low self-esteem will significantly cause depressive symptoms which will affect their pregnancy [33].

The third is the lack of family and partner support. Pregnant adolescents who lack support from their families, especially mothers and their partners, will feel depressed and have feelings of sadness and hopelessness. Other studies have shown that greater support from mothers and partners reduces the severity of depression [34]. The fourth, access to health services barriers. According to Kumar et al., health workers still have a negative attitude in providing pregnancy health services to pregnant adolescents [35]. Health workers are expected to be friendly to pregnant adolescents because if the health workers give a negative attitude, the adolescents will perceive it as a punishment for 
their actions, which will hinder the care of the teenage pregnancy itself [32]. The fifth is personal characteristics. A history of drug use, alcohol use, depression, and sexual abuse can increase adolescent's chances of developing prenatal depression.

According to the American College of Obstetricians and Gynecologists, depression is described as more than feeling sad or upset for a short time, but depression can change the thoughts, feelings, behavior, and physical health of sufferers [36]. According to the World Health Organization, depression is a mental disorder characterized by persistent sadness and loss of interest in activities, depression is also associated with a person's inability to participate in daily activities for at least 2 weeks. In addition, a person with depression usually experiences symptoms such as loss of energy, changes in appetite, sleep problems, restlessness, reduced concentration, restlessness, feelings of worthlessness, guilt or hopelessness, and thoughts of self-harm and suicide [37].

Depression in pregnancy can reduce a person's ability to perform self-care, including inadequate nutrition, drug or alcohol abuse, and irregular ANC visits [38]. These conditions can endanger the health of the mother and fetus as a result of the lack of optimal fetal monitoring so that it can limit fetal growth and development, it is also reported that mothers with depression during pregnancy will give birth to babies with low birth weight (LBW) or prematurely [38].

It is necessary to take early action to manage depression in pregnant adolescents. Early management of depression in teenage pregnancy is needed to prevent and reduce the severity of depression. According to Boobpamala et al., the main step in the management of depression in pregnant adolescents is screening for all pregnant women [32]. In addition, adolescents with adverse events need to be ensured that they have strong support from their families and partners. In addition, nurses need to conduct health education to increase adolescent knowledge about self-care and fetal care. This support and increased knowledge will reduce anxiety and sadness so that it will slowly reduce symptoms of depression. In addition, health service providers and the community must provide information and supporting resources such as access to ANC services, medical costs, and counseling regarding health care during pregnancy, childbirth, and postpartum.

\section{Conclusion}

Based on the results of several research articles, it can be concluded that the impact of unwanted pregnancy on pregnancy care in adolescents will have an impact on both physical and psychological problems, including adolescents do not perform ANC during their pregnancy, adolescents tend to make efforts to abort their pregnancy, do not consume healthy food and balanced nutrition, do not consume iron-enhancing tablets, do not do physical activities and sports, lack of sleep, and rest, adolescents tend to ignore personal hygiene, adolescents do not stimulate their fetuses, shut down, and are depressed. Adolescents with adverse events tend not to take care of their pregnancy and behave dangerously to their fetuses. Therefore, support from families, health workers, and the community is needed so that adolescents with unwanted pregnancy continue to take care of their pregnancy. By performing the optimal pregnancy care for adolescents with adverse events, it can prevent pregnancy complications and with good support, it is hoped that adolescents can accept their pregnancy so that it does not cause depression.

\section{References}

1. United Nation Population Fund. Motherhood in Childhood: Facing the Challenge of Adolescent Pregnancy. United Nation Population Fund; 2013. Available from: http://www.unfpa.org/ publications/state- world-population-2013 [Last accessed 2021 Oct 01]

2. Wakhidah EN, Cahyo K, Indraswari R. Factors Associated with Antenatal Care Practices for Adolescents with Unwanted Pregnancy (Study in the UPT Territory of Ponjong 1 Public Health Center, Gunungkidul Regency). J Kesehat Masy. 2017;5(5):958-68.

3. Setyaningsih MM. Fetal stimulation, baby's temperament analysis of the effect of fetal stimulation on baby's temperament. J Keperawatan Malang. 2017;2(1):8-17.

4. de Azevedo WF, Diniz MB, da Fonseca ES, de Azevedo LM, Evangelista CB. Complications in adolescent pregnancy: Systematic review of the literature. Einstein (São Paulo). 2015;13(4):618-26. https://doi.org/10.1590/ S1679-45082015RW3127

PMid:26061075

5. Dini LI, Riono P, Sulistiyowati N. The Effect of Unwanted Pregnancy Status on Maternal Behavior During Pregnancy and After Birth in Indonesia (2012 IDHS Data Analysis). J Kesehat Reprod. 2016;7(2):119-33.

6. Fitrayeni F, Suryati S, Faranti RM. The cause of the low completeness of antenatal care visits for pregnant women in the Pegambiran Health Center Working Area. J Kesehat Masy Andalas. 2017;10(1):101-7.

7. Hardiani RS, Purwanti A. Motivation and adherence to antenatal care (ANC) visits in third trimester pregnant women. J Keperawatan. 2012;3(2):2595.

8. Elvahra Z. Peran Perawat Dalam Pengambilan Keputusan Untuk Meningkatkan Pengetahuan Terkait Tindakan Aborsi Pada Remaja Akibat Kehamilan Tidak Diinginkan (KTD); 2020.

9. Amalia $\mathrm{EH}, \mathrm{Azinar} \mathrm{M}$. Kehamilan tidak diinginkan pada remaja. HIGEIA. 2017;1(1):1-7.

10. Mann ES, Cardona V, Gómez CA. Beyond the discourse of reproductive choice: Narratives of pregnancy resolution among Latina/o teenage parents. Cult Health Sex. 2015;17(9):1090-104. https://doi.org/10.1080/13691058.2015.1038853

PMid:25953108 
11. Pane HW, Tasnim, Sulfianti, Hasnidar, Puspita R, Hastuti P, et al. Gizi dan Kesehatan. Indonesia: Yayasan Kita Menulis; 2020.

12. Ernawati A. Nutritional problems in pregnant women. J Litbang. 2017;13(1):60-9.

13. Muliawati S. Factors causing pregnant women to have chronic lack of energy at the Sambi Public Health Center, Sambi District, Boyolali Regency in 2012. J INFOKES Univ Duta Bangsa Surakarta. 2016;3(3):115. https://doi.org/10.47701/infokes. v3i3.115

14. Rizki F, Lipoeto $\mathrm{NI}$, Ali $\mathrm{H}$. The relationship between Fe tablet supplementation and hemoglobin levels in third trimester pregnant women at the Air Cold Public Health Center in Padang City. J Kesehat Andalas. 2018;6(3):502-6.

15. Amanah IR. Pharmacoepidemiological study of blood-boosting vitamins in pregnant women in Jatinangor District. J Kesehat Vokasional. 2019;4(3):153-60.

16. Juwita R. The relationship between counseling and family support on the compliance of pregnant women taking Fe tablets. J Endur Kaji IIm Probl Kesehat. 2018;3(1):112-20.

17. Levey AS, Coresh J. Chronic kidney disease. Lancet. 2012;379(9811):165-80. https://doi.org/10.1016/ S0140-6736(11)60178-5 PMid:21840587

18. Newton ER, May L. Adaptation of maternal-fetal physiology to exercise in pregnancy: the basis of guidelines for physical activity in pregnancy. Clin Med Insights Womens Health. 2017;10:17693224. https://doi.org/10.1177/1179562X17693224 PMid:28579865

19. Suryani P, Handayani I. Senam hamil dan ketidaknyamanan ibu hamil trimester ketiga. J Bidan. 2018;4(1):33-40.

20. Mediarti D, Sulaiman S, Rosnani R, Jawiah J. The effect of antenatal yoga on reducing complaints of pregnant women in the third trimester. J Kedokt Dan Kesehat Publ IIm Fak Kedokt Univ Sriwij. 2014;1(1):47-53.

21. Lestari DP, Gani HA, Nafikadini I. Pregnancy care behavior in adolescents with unwanted pregnancies in the widodaren subdistrict, Ngawi district. J Kesehat. 2019;7(3):128-39.

22. Bustami LE, Nurdiyan A, Yulizawati YY, Iryani D, Fitrayeni $F$, Insani AA. Effect of sleep quality on pregnant women with the incidence of preeclampsia. J Midwifery Res Pract. 2016;1(1):3544. https://doi.org/10.25077/jom.1.1.35-44.2016

23. Iriyanti A, Suryawati $C$, Nugraheni SA. Behavioral factor analysis of unwanted pregnancy in adolescents in Karangrayung sub-district, Grobogan district. J Manaj Kesehat Indones. 2018;6(2):159-64.

24. Subrakti ST. Gambaran Pengetahuan Ibu Hamil tentang Personal Hygiene Selama Kehamilan di Klinik Romauli; 2019.

25. Anggraini R, Andreas P. Oral Dental Health and Utilization of Oral Dental Health Services for Pregnant Women (Preliminary Study in the Serpong Community Health Center, South Tangerang). Maj Kedokt Gigi Indones. 2015;1(2):193-200.

26. Suri $M$, Nelliraharti $N$. The intensity of communication between pregnant women and the fetus as a stimulus for hearing and brain development in introducing vocabulary. J Educ Sci.
2019;5(2):33-7.

27. Rochanah S, Idriani I, Sulaeman S. The effect of talk, touch, and combination of both talk and touch stimulation on movement and fetal heart rate among mother with high-risk pregnancy. Int J Nurs Health Serv. 2020;3(2):200-6.

28. Fatmawati $E$. Differences in the influence of the provision of simulation between classical and murottal music on fetal heart rate in pregnant woman trimester II and III. Univ Sebel Maret. 2013;70-7.

29. Malik D, Astuti AB, Yulianti NR. Pengalaman hidup remaja yang hamil di luar nikah In: Studi Fenomenologi di Desa Baru Kecamatan Ibu Halmahera Barat. 2015; 4(2). 259-85

30. Rani Y, Muhibbin A. Keterbukaan Diri Anak Yang Hamil Diluar Nikah Kepada Orangtua. Surakarta: Universitas Muhammadiyah Surakarta; 2018.

31. Aziato L, Hindin MJ, Maya ET, Manu A, Amuasi SA, Lawerh RM, et al. Adolescents' responses to an unintended pregnancy in Ghana: A qualitative study. J Pediatr Adolesc Gynecol. 2016;29(6):653-8. https://doi.org/10.1016/j.jpag.2016.06.005 PMid:27346553

32. Boobpamala S, Kongvattananon P, Somprasert C. Early management of depression in adolescent pregnancy: An integrative review. J Behav Sci. 2019;14(1):97-113.

33. Jesse DE, Kim H, Herndon C. Social support and self-esteem as mediators between stress and antepartum depressive symptoms in rural pregnant women. Res Nurs Health. 2014;37(3):241-52. https://doi.org/10.1002/nur.21600 PMid:24797585

34. Pires R, Araújo-Pedrosa A, Canavarro MC. Examining the links between perceived impact of pregnancy, depressive symptoms, and quality of life during adolescent pregnancy: The buffering role of social support. Matern Child Health J. 2014;18(4):789800. https://doi.org/10.1007/s10995-013-1303-0 PMid:23793535

35. Kumar M, Huang KY, Othieno C, Wamalwa D, Madeghe B, Osok $\mathrm{J}$, et al. Adolescent pregnancy and challenges in Kenyan context: Perspectives from multiple community stakeholders. Glob Soc Welf. 2018;5(1):11-27. https://doi.org/10.1007/ s40609-017-0102-8

PMid:29744286

36. American College of Obstetricians and Gynecologists. ACOG statement on Depression Screening. States: American College of Obstetricians and Gynecologists; 2016.

37. World Health Organization. Mental Health. Geneva: World Health Organization; 2016. Available from: http://www.who. int/mental_health/management/depression/en/\%0A [Last accessed on 2021 Oct 01].

38. Ayele TA, Azale T, Alemu K, Abdissa Z, Mulat H, Fekadu A. Prevalence and associated factors of antenatal depression among women attending antenatal care service at Gondar University Hospital, Northwest Ethiopia. PLoS One. 2016;11(5):e0155125. https://doi.org/10.1371/journal.pone.0155125

PMid:27153193 